\title{
The effects of the armed conflict on the life and health in Colombia
}

\author{
Os efeitos do conflito armado sobre \\ a vida e a saúde na Colômbia
}

Saúl Franco 1

Clara Mercedes Suarez 1

Claudia Beatriz Naranjo 1

Liliana Carolina Báez ${ }^{1}$

Patricia Rozo ${ }^{1}$

\footnotetext{
1 Universidad Nacional de Colombia.

Abstract This article is an approach to the consequences of the internal armed conflict that Colombia has lived during the last four decades. It starts with the identification of the conflict's context and its current characteristics. It then focuses on the different manifestations and consequences of the conflict and on their deep impact on the life, quality of life, health, disease, and health services of the population. In special we refer to the high homicide rates, forced internal displacement, kidnapping and the use of antipersonnel mines. Among the most affected groups are young men, women, children, and ethnic minorities such as indigenous and afro-american people. This analysis also refers to the frequent violations of International Humanitarian Law and to the negative impact of violence on the provision of health services. Finally, general conclusions are drawn, and alternatives for studies on the problem and for possible solutions from the standpoint of the health sector are proposed.

Key words Violence in Colombia, External causes, Internal armed conflict, Health services
Resumo O presente trabalho trata das conseqüencias do conflito armado interno (CAI) que a Colômbia tem vivido durante as últimas quatro décadas. Começa identificando o contexto e o momento atual do conflito. A seguir, são descritas algumas das formas, expressões e conseqüências do conflito armado interno com maior impacto sobre a vida, a qualidade de vida, a saúde e as doenças da população, e sobre os serviços de saúde no país. Especial ênfase é dada às altas taxas de mortalidade por homicídio, ao fenômeno do deslocamento forçado pela violência, aos seqüestros e às minas antipessoais. Entre os grupos populacionais mais afetados, destacam-se homens jovens, mulheres, crianças e as minorias étnicas indígenas e afrodescendentes. Esta análise também se refere ao sério problema das contínuas infrações da Lei Humanitária Internacional e aos ataques contra a Missão Médica, assim como às conseqüências negativas do conflito sobre a prestação de serviços de saúde. Para concluir, são feitos alguns comentários gerais sobre a situação descrita e dadas algumas sugestões para o estudo do problema e possíveis ações partindo do setor saúde. Palavras-chave Violência na Colômbia, Conflito armado interno, Causas externas, Serviços de saúde 


\section{Introduction}

For almost four decades now, Colombia is living an intense internal armed conflict, result of confrontations between the State and different illegal armed organizations. The Colombian internal armed conflict is rooted in a prior cycle of violence occurred between the traditional political parties in the 40 s and 50 s of the 20th century. In its present stage, however, it is the result of the establishment of guerilla organizations since the 60 s of the 20th century, worsened by the irruption and expansion of drugs trade in the beginning of the 70s and the paramilitary organizations that appeared in the beginning of the 80 s.

During this period the internal armed conflict increased and won complexity given the diversity of actors, the coincidence of processes encouraging the conflict and the involvement of different sectors of the civil society. Concomitantly, the rates of different forms of violence such as homicides, disappearances, forced displacements and kidnapping reached levels never seen before in the country. The quality of life of the Colombian people was seriously affected by the conflict and the health sector itself suffered the negative impacts of the violence and became increasingly a direct victim of the different actors of the conflict.

Different studies are calling attention to the extent of the phenomenon of violence in Colombia, in special to the negative impact of the internal armed conflict on the life and health of the Colombian people and on the health sector in different regions of the country. Beginning with a brief description of the moment and the context of the Colombian internal armed conflict, this article seeks to provide a picture of the severe consequences of the mentioned conflict for the life, mortality and morbidity of the population, in special with regard to certain particularly vulnerable groups and to the health services. The article concludes with some analytical considerations and proposals for the health sector and for the sectors of the international academic community interested in analyzing the relations between armed conflict and health, and in finding a solution for the Colombian conflict.

\section{The internal armed conflict in Colombia}

In the first place it must be made clear that what Colombia is dealing with is an internal armed conflict and not a civil war or an unarticulated succession of terrorist actions. In general, three characteristics are accepted for classifying an internal armed conflict: first, the opposing parties have a clearly different legal status; second, the actions of the armed groups follow the orders of a responsible command, which does not necessarily mean a hierarchic military organization like in the Army; and third, the criminal activities pursue systematically a defined political or ideological purpose and seek to control part of the territory 1 , an aspect distinguishing the armed conflict from the sudden increase of isolated violent acts.

The above characteristics identify the phenomenon of violence Colombia is facing clearly as an internal armed conflict. On one hand, we have the armed guerilla groups known as Fuerzas Armadas Revolucionarias de Colombia-FARC (Revolutionary Armed Forces of Colombia), and Ejército de Liberación NacionalELN (National Liberty Army). These groups are committing acts of violence of different nature, follow organized commands recognized among their members and control certain areas and regions of the country. The same refers to the appearance and strengthening of the illegal paramilitary groups like the Autodefensas Unidas de Colombia-AUC (United Self-Defense Forces of Colombia). These groups appeared in part as an answer to guerilla activity but also as organizations in the service of landlords, cattle raisers, agro-industrialists and drug dealers.

The processes that gave origin and force to the internal armed conflict in Colombia were in short the following: lack of legitimacy and the progressive corruption of the State; absence of democratic spaces for a pacific solution of the controversies; accumulation of unsolved crises and conflicts; chronic and increasing economical, political and social insecurity; inequality and social exclusion of great sectors of the population; precariousness and inefficiency of the justice system with the resulting climate of impunity; intolerance to cultural and political differences and different values; and the influential drugs trafficking and arms smuggling as a basis for its maintenance and expansion ${ }^{2}$.

The internal armed conflict is no more a basically focal and rural phenomenon; it is present everywhere, exerting different effects on different sectors of the country. Although some governments have tried to reach a negotiated political settlement with some of the illegal 
groups, the predominant answer of the State has been military repression. In fact, the different actors in the conflict in Colombia engage in approximately 2,500 armed combats per year, resulting in the death of more than 3,000 combatants ${ }^{3}$. Today, intense military confrontations with the guerilla organizations are taking place, while a controversial process of negotiations is being undertaken with the paramilitary groups. The whole problem becomes critical basically due to four aspects: the persistence and worsening of the factors determining the conflict; the increase and intensification of the conflict unleashing a true humanitarian crisis in which one is no longer able to distinguish between combatants and civil population; the real or potential risk of the problem compromising the stability of the region; and finally the importance Colombia has in the current North American agenda related to drug production, trafficking and use, given that the country produces one third of the total of cocaine produced worldwide and participates actively in narcotics trafficking 4 .

According to the International Humanitarian Law, the recognition of an internal armed conflict by a government does not imply in any legal status to the conflicting parties nor does it limit the possibility of solving the conflict by any of the established means or to sue and sentence the adversaries; on the contrary, it enforces the application of the international treaties ${ }^{1}$.

\section{The effects of the armed conflict on the life and health of the Colombian population}

The different consequences of the Colombian armed conflict for the life, the quality of life, the health, health care and disease prevention in the country are serious and complex. For approaching them, it is unavoidable to establish the relation between specific forms of violence and their main victims. Several phenomena have been observed as an expression and at the same time as a consequence of the conflict, able to affect a variety of victims by interfering not only in their quality of life but also in distinct physical, emotional and psychosocial dimensions of their health. Knowing these difficulties, we present the most relevant aspects of the issue in question, describing in the first place four serious forms of today's violence and their impact on the life and health: homicides, forced displacement, kidnappings and antipersonnel mines. We show the magnitude of each of these phenomena and their main modalities and implications, with special reference to children and women victimized by the conflict. Then we outline two of the main consequences of the conflict to the health system: the alterations in the delivery of health services and the attacks against the Medical Mission.

\section{Colombia: a homicidal country?}

Given that between 1975 and 2004, 554,008 homicides were committed in the country, a mean of one homicide each half an hour during the period, representing 10 to $15 \%$ of the total mortality rate ${ }^{5}$, the answer to this question is shamefully yes. In spite of the homicide curve in Colombia during the last thirty years (Graph 1) being the result of different processes and forms of violence, there is a clear relation between this curve and the development of the internal armed conflict. The extreme increase of the homicide rates per 100 thousand inhabitants occurs since the mid-70s and reaches its peak in 1991, with 81 homicides/100 thousand inhabitants. Since then, there were oscillations in the curve, with a marked decrease since 2003. The reason for this decrease is still not clear but there are several hypotheses: one of them relates the fact to the democratic security policy established by the current government, based on military repression of the guerilla, with a considerable increase of the budget and power of the troops. Part of this policy is the demobilization of some of the paramilitary groups, whose participation in the homicides was very high. Another hypothesis links the decrease in the number of violent deaths to the policies and programs for urban safety and citizenship carried out on local level, as occurs in the cities of Bogotá and Medellin. On the contrary to what is happening in some of the big cities, in many small cities of the country, whose statistics does not make much difference in the national data, the cases of deadly violence are increasing6.

Analyzing the homicide rates on the basis of age and sex, one observes 5 that the main victims were young and always younger males, involving even boys with less than five years of age. In 1994, in the division of Antioquia, whose capital is Medellin, homicides were responsible for more than half $(53 \%)$ of deaths of boys between 10 and 14 years of age and for $87 \%$ of 
Graph 1

Homicide rates in Colombia 1975-2005.

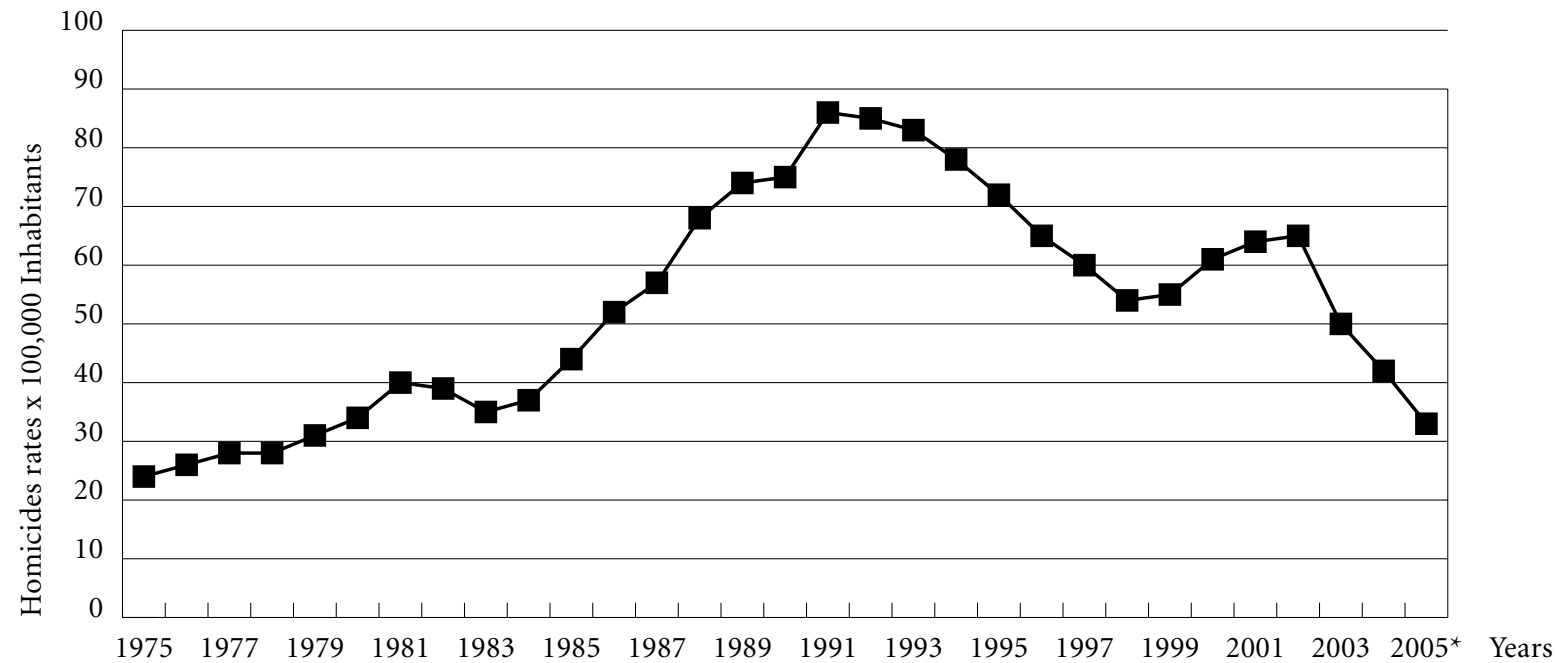

Source: National Institute of Legal Medicine and Forensics, National Police and CINEP.

deaths of adolescents between 15 and 19 years of age. Although women were relatively less frequently victims of homicide than men, the proportion had dropped in less than ten years from 18 men per one woman to 13 men per one woman, indicating a progressive increase in homicides of women.

With respect to the different regions of the country the homicide rates vary significantly, very well expressing the dynamics of the conflict and the stronger or weaker response of the society and of the State on regional level. Recently, divisions like Antioquia are leaving the first places in homicide rates and divisions in the east and south of the country with formerly low homicide rates are occupying the first places now: Guaviare in 2001, Arauca in 2002, Casanare in 2004. The increase of the illegal plantations and related drug trafficking, the weak presence of the State, the exploitation of oil and the fights between the different armed actors for obtaining the control of a territory explain to a good part this trend and the dynamics of the deadly violence.

On the other hand, there are the frequent massacres, understood as collective homicides more than four deaths per episode - committed intentionally and in a programmed manner against defenseless victims with the intent to immobilize people by causing fear and to establish political and territorial control, and representing an extreme violation of the International Humanitarian Law. According to the UNDP, between 1997 and 2002 a total of 930 massacres occurred in the country, a mean of one massacre per day, producing a total 2,630 fatal victims ${ }^{7}$.

An estimation of the number of deaths directly related to the internal armed conflict carried out by the UNDP in 2003 found that between 4 and 8 thousand Colombian people die yearly as a direct result of this war. Using a mean of 6,000 fatal victims per year due to the internal armed conflict, one would find that during the last 25 years Colombia lost 150,000 lives as a direct result of the conflict, not considering its contribution, through different mechanisms and interactions, to the generally high homicide rates in Colombia.

Another form of estimating the impact of violence and of the armed conflict on the life of the Colombian population is observing the behavior of the life expectancy, especially comparing the behavior of this indicator among men and women in the country. The life expectancy at birth of the Colombian population as a whole increased, but the rhythm of this increase slowed down and the difference between men and women increased, to a good part as a 
result of deadly violence. According to the Pan American Health Organization 8 , in 2004 the life expectancy at birth for women is of 75 years and for men of 69 years, shall say a difference of six years in favour of the women. The UNDP in its already mentioned report estimates that only in the 90s the Colombians lost between one and a half and two years of their life expectancy due to violence.

\section{The tragedy of forced displacement due to violence}

According to data of the Colombian Episcopal Conference and the nongovernmental organization Counseling on Human Rights and Displacement (CODHES), between 1985 and 2005 more than three million and six hundred thousand Colombians have been victims of forced displacement due to violence ${ }^{9}$, as can be seen in graph 2. According to the same source, $30 \%$ of this total, $2,100,000$ individuals, have been displaced during the last three and a half years. Approximately half of the population displaced due to violence has less than 18 years of age ${ }^{10}$. According to a study carried out by the Social Parish11, $46.5 \%$ of this population is younger than 15 years, a number similar to the $48.5 \%$ found for the same class in the investi- gation of the Pan American Health Organization and by the University of Antioquia in 200312. UNICEF and CODHES13 estimate that between 1985 and 2002 about 1,750,000 children had to escape from their places of origin in the country. Only in 2005, a total of 310,000 people were displaced in the country. Seven hundred and fifty municipalities lost residents and 950 received displaced population. According to official information provided by the Red de Solidaridad Social (Social Solidarity Network) ${ }^{14}$, a governmental organization in charge of the displacement problem, $90 \%$ of displaced people are of rural or semi-rural origin, and one third of them own or owned land in their places of origin; $50 \%$ settle in the miserable outskirts of the big cities; $9.2 \%$ belong to AfroColombian communities and $34 \%$ to indigenous communities.

The consequences of the displacement vary according to gender, age and ethnic group, former economical level, kind of displacement, destiny and the conditions of insertion into the new environments. In children and adolescents, the deterioration of their environment and displacement turns them more vulnerable to malnutrition, diseases of the skin and infecto-contagious diseases. From every 100 displaced children between one and four years of age, only

\section{Graph 2}

Forced displacement in Colombia 1985-2005.

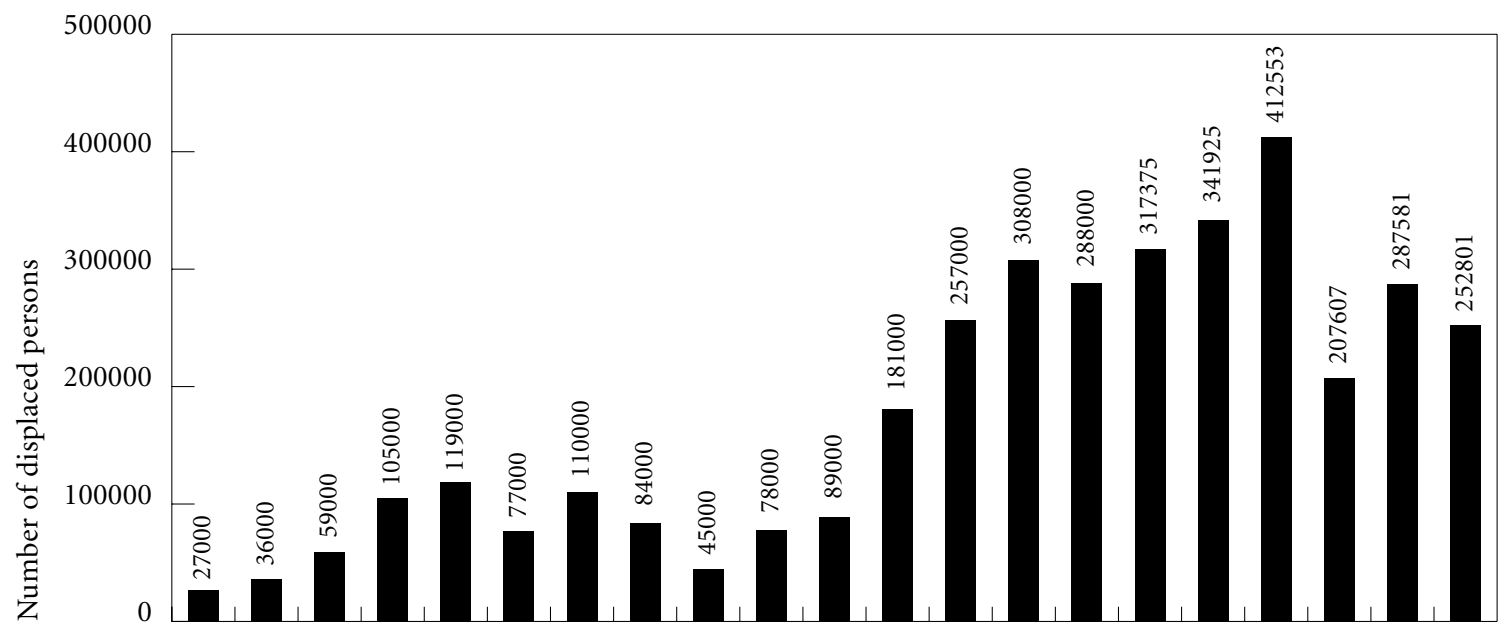

$198519861987198819891990199119921993199419951996199719981999200020012002200320042005^{\star}$ 
two received the complete vaccination scheme. Thirty-five of each 100 displaced adolescents get pregnant, the double of the national mean according to the already mentioned PAHO study. To this comes discrimination, more difficult access to health services, disintegration of the families, physical and sexual abuse, exploitation of labor, and the resulting effects on the mental health.

The adult population - with more than 19 years of age - represents $50 \%$ of the total of displaced individuals, with a higher percentage of women than men. The proportion of illiteracy in women increases with age, varies according to regions and ethnic groups and reduces the chances of employment. The average number of children of displaced women is three and the greater part of women assumes the role of head of the family and the consequent economical responsibility 15 , or for having lost their husbands or partners in the conflict or because these had abandoned their familiar responsibilities under the new circumstances. In the studies on gender of the United Nations High Commissioner for Refugees, who is in charge of the displacement problem in Colombia, the ruptures and losses caused by the forced displacement are felt more intensely by women than by men, but in the urban environment men use to be more affected by unemployment than women 16 .

Between $3 \%$ and $6 \%$ of the population in a situation of displacement are older than 60 years. In this age group, $70 \%$ of displaced people are women, given that aged men are more reluctant to leave their land and their environment. As in the dynamics of the internal armed conflict, it is mostly the young men who join the armed groups or become victims of homicides. In many cases, grandfathers and grandmothers are taking care of the family, living hidden away in their houses, socially almost invisible and under very poor economic, hygienic and health conditions.

The negative impact of the IAC on the indigenous population, in particular of displacement and confinement, has to be emphasized here. It is estimated that $57 \%$ of indigenous villages of the country are directly affected by the internal armed conflict 17 . The confinement imposed by the armed actors is one of the most serious consequences of the conflict for this population, to which currently one out of three indigenous individuals is subject. Both displacement and confinement of indigenous popula- tions are more intense in the regions with a greater indigenous component, such as Cauca, Caquetá, Chocó, Valle del Cauca, La Guajira and Vaupés 18 . The most affected indigenous villages were in this order: Embera, Nasa, Embera Chamí, Wiwa, Embera Katío, Kankuamo, Pijao, Guahibo, Wayú and Awa. In addition to the serious consequences displacement brings to all of its victims, for the indigenous population the displacement from the grounds of their ancestors still means losing their sense of life, they suffer a greater loss of culture and are more subject to extinction.

As refers to access to health services, it is estimated that two out of ten displaced individuals do not possess any document, which would allow for access to the health services. In addition, due to the difficulty of being recognized as displaced person, to the high cost of medical consultations and remedies as well as a certain institutional discrimination, around $30 \%$ of displaced individuals are deprived from access to medical care ${ }^{8}$.

\section{The horror of the kidnappings}

Kidnapping, understood as detention of persons against their will, is one of the most severe violations of human rights, constituting a crime against humanity. Due to its characteristics and uncertain outcome, kidnapping interferes not only with the quality of life of the victim but also of the persons of his familiar, working and political environment, with severe consequences for their health, especially the mental health.

There are different kinds of kidnapping. The most important for the issue being discussed here is the kidnapping for ransom, frequently combining economical and political elements. In fact, in the Colombian internal armed conflict, kidnapping has become a frequently used mechanism for financing the illegal armed organizations and for achieving political objectives, like transmission of messages through highly representative personalities or imprisonment of personalities for exchanging the prisoner or as a demonstration of power.

The available figures show an alarming increase of cases of kidnappings during the same period in which the internal armed conflict developed, demonstrating its progressive worsening. In the 70s, an average number of 55 people were kidnapped per year. In the $80 \mathrm{~s}$, the annual mean increased to 296 cases, with a peak of 781 
cases registered in 1989 . In the 90 s, the yearly mean of kidnappings in the country reaches the alarming number of 1,508 cases. In the year 2000 we register the highest peak of the whole period with a total of 3,706 kidnappings (shown in graph 3), a mean of ten kidnappings per day. At that time, a terrible form of collective kidnapping reached its climax, a technique, taking hostage of groups of people for selecting the definitive victims later, known as "miracale fishing". Since the year 2000 we observe an apparently significant decrease of the phenomenon, but there are serious doubts with respect to the trustworthiness of the registries. According to statistics of the Observatory for Human Rights of the Vice-Presidency of the Republic, much lower than those shown in graph 3, in 2004, $73 \%$ of victims of registered kidnappings $-908-$ were of masculine sex, while the resting $27 \%$ 342 - were women. Of the 1,250 persons victims of kidnappings registered in that year by the Observatory, 222, corresponding to $18 \%$ of the total number, were minors.

Worse than the kidnappings are the forced disappearances. According to the Inter-American Convention on Forced Disappearance of People, of 1993, forced disappearance is considered to be the act of depriving a person or persons of his or their freedom, in whatever way, perpetrated by agents of the State or by persons or groups of persons acting with the authorization, support, or acquiescence of the State, followed by an absence of information or a refusal to acknowledge that deprivation of freedom or to give information on the whereabouts of that person, thereby impeding his or her recourse to the applicable legal remedies and procedural guarantees ${ }^{19}$.

There is a great diversity and inconsistence of data on disappearances, which is due to the criteria used for defining the phenomenon and to the institutions that register the information. According to CINEP, in the first semester of 2005, 35 cases of forced disappearance due to political persecution were registered in the country. Of them, $86 \%$ were attributed to paramilitary groups. During the same period, 25 cases of forced disappearances were registered, as a result of political-social violence perpetrated by unknown authors. The International Committee of the Red Cross 20 informs that, in 2004, 279 cases of forced disappearance were related to the internal armed conflict in the country. According to the same source, this figure should be added to the more than 2,000 cases registered since 1994. It is intriguing that in spite of the seriousness of the disappearances

\section{Graph 3}

Kidnappings in Colombia 1996-2005.

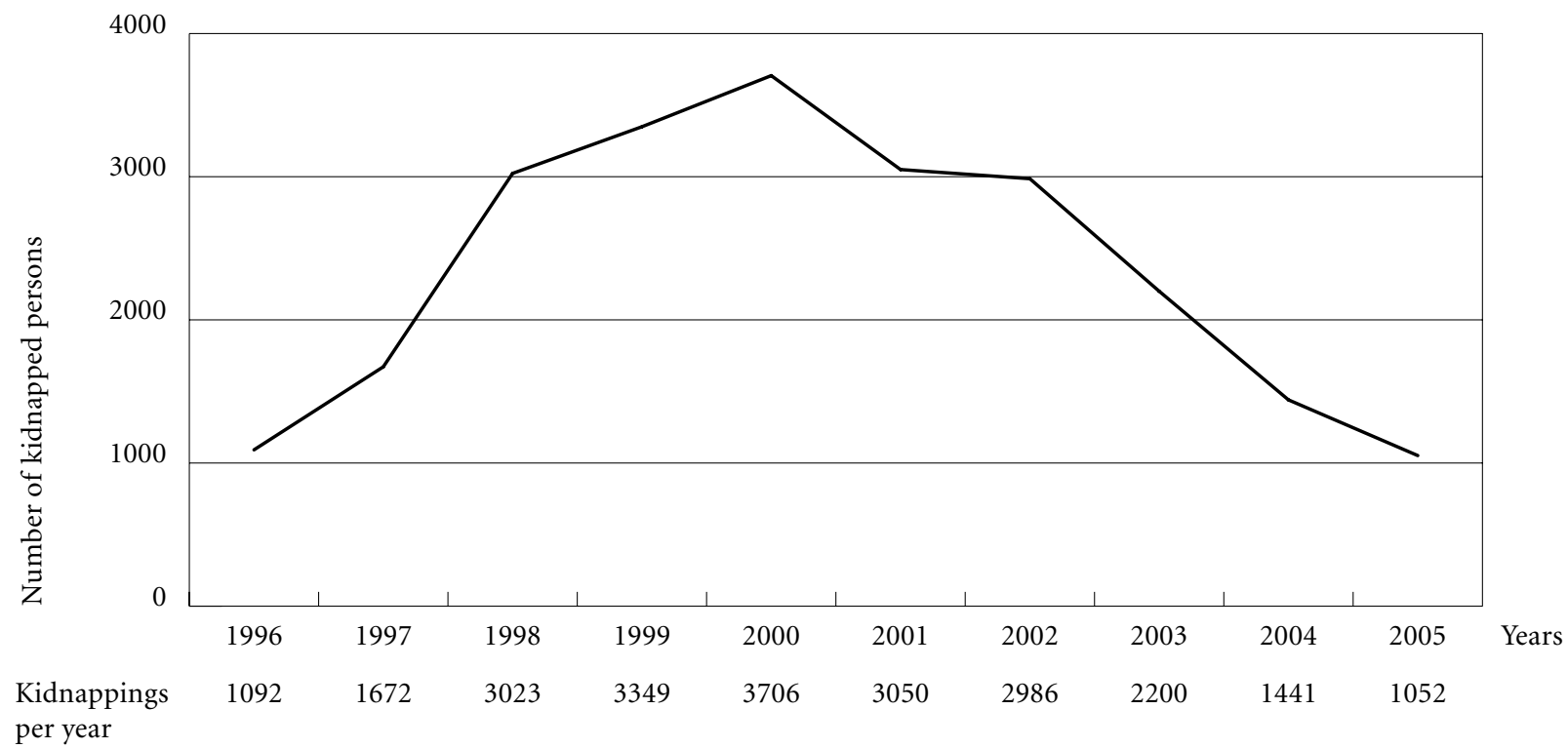


and their consequences for the quality of life of the victims and their familiar and political environment, they are having very little impact in the communication media and in the debates on the conflict.

\section{The serious damages caused by antipersonnel mines}

Another indicator for the intensification and the worsening of the Colombian armed conflict is the increasing use of antipersonnel mines. Their difficult detection and lethal effect or the serious physical damages such as mutilations, amputations, loss of vital organs and complex psychological sequels in the victims themselves, and their personal emotional relationships, make them to highly noxious weapons violating the International Humanitarian Law. Given that a not inactivated mine can be lethal up to 50 years after having been buried in the soil, this "prolonged action" of the armed groups can lead to an extension of the conflict and its unlucky consequences. The registries of these events are not precise and biased. According to data from the National Army, between 1990 and June 2002, Colombia has been victim of more than 1,800 events generated by explosives used by illegal armed groups ${ }^{21}$. According to the same source, in 411 municipalities situated in 30 of the 32 administrative divisions of the country the said artifacts were present. A recent newspaper report 22 points to an alarming increase in the use of antipersonnel mines. They are already present in 627 municipalities of the country, corresponding to more than $50 \%$, and produced in 5 years 2,358 victims. The VicePresidency of the Republic reports for the period 1990 to September 2003 a total of 3,409 events involving explosive devices. The corresponding numbers for the following years were 116 victims in 2000, 147 in 2001 and 384 victims in $2002^{23}$. According to a recent publication, between January and September 2004, 421 new victims of mines were registered in the country, 109 of them died and 321 were wounded. From the total of victims of the period, 127 were civilians, seven of them women and 31 children. It is estimated that, in overall terms, $14 \%$ of victims are children.

The efforts of different national and international institutions and organizations for "demining" the country notwithstanding, the problem and its consequences continue increasing as shown by the presented figures. An aggravating factor is that while nearly all countries are supporting and promoting the mine ban, some of the main producers of antipersonnel mines, among them the United States of America, refuse to sign the international treaty prohibiting their production.

\section{Children and women in the armed conflict}

Since the beginning of the current internal armed conflict, there is the concern with the military use of boys and girls in the legal and illegal armed groups. Since the 90s however, the problem grew worse and passed to call attention on national and international level. According to estimations of the General Secretary of the United Nations, the Colombian Justice Department, the United Nations Children's Fund (UNICEF) and the Human Rights Watch, the number of children present in the illegal armed groups in the country is estimated between 11,000 and 14,000 . This transforms Colombia into the fourth country in the world in terms of numbers of armed children. It is estimated that from this total about 6,000 boys and girls, the greater part of them in the age group between 7 and 13, make part of guerilla organizations, and that $15 \%$ of members of paramilitary groups have less than 18 years of age. The military age of 18 years was only in 1999 established by law in the country. The greater part of children and adolescents - 13 to 17 years - recruited by the armed actors are of rural origin, members of numerous families whose head is generally the mother, a grandmother or another relative. Many of them were victims of family violence, have poor educational level and were in general early bonded into agricultural labor. In the scenery of the conflict on the other hand, they are not only deprived from their childhood, but also transformed into actors and victims of violence at the same time. In an environment of adult warriors under very difficult circumstances, their safety and integrity is permanently at risk and many times these children suffer physical, sexual and psychological violence. Such circumstances leave marks difficult to be erased in later life in case these children survive the conflict.

The Colombian Institute for Family Welfare in cooperation with other governmental, nongovernmental and international organizations has carried out different actions for preventing the involvement and recruitment of children and adolescents by illegal armed groups 24 . 
Although some women are participating in armed organizations - governmental, insurgent and paramilitary - according to their own free will, many other women were and still are victims of the armed conflict. According to a document of the United Nations ${ }^{25}$, the situation of women and girls making part of illegal armed groups continues concerning the Council. Women and girl-combatants were objects of sexual abuse by their superiors in the hierarchy [...] There is no special program for reinsertion of excombatant women.

\section{The impact of the armed conflict on the health sector}

The armed conflict has a variety of consequences for the health sector, for its institutions, its personnel and the funds destined to qualification of medical and paramedic personnel, health research and formulation and implementation of health policies. Besides posing urgent demands to the health care services as refers to timely and appropriate care for victims, the internal armed conflict also consumes great part of the resources of many health institutions and raises serious questions regarding the schemes and models of qualification of health personnel, the health policies of the country and the priorities in health research.

Given the spatial limitations of this article, we will only refer to two specific and very important problems the Colombian armed conflict creates to the health sector: the attacks against the Medical Mission and the problems and limitations they cause to the delivery of health care services.

\section{The frequent attacks against the Medical Mission}

Understood as the whole set of persons, installations, material, equipment and activities directed to the delivery of health care services in situations or regions of armed conflicts, the Medical Mission is protected by the International Humanitarian Law, by the four Geneva Agreements, by the II Additional Protocol to the Geneva Agreements and by article 3, common to the mentioned agreements. In the case of Colombia, the mission still counts on a decree that establishes an emblem to identify the Medical Mission, its personnel and institutions nationwide 26 .
Different investigations show the seriousness and frequency of the attempts upon the Medical Mission in Colombia. According to a study carried out by the International Committee of the Red Cross ${ }^{27}, 468$ infractions against the Medical Mission were committed between 1995 and 1998. Most of them attempted upon the life and the integrity of personnel, followed by attacks against the infrastructure. Seventy-six of the 341 victims produced by these actions belonged to the health sector. A recent study of the Ministry for Social Protection and $\mathrm{PAHO}^{28}$ registered a progressive increase of attacks in the period 1999-2002, passing from 29 cases registered in 1999 to 236 in 2002. According to the Institute for Studies on Development and Peace, between 1999 and 2002, 279 employees of the sector received threats. Until August 2004, 662 attacks with 604 victims were registered. Of these, $98 \%$ victims suffered attacks against their life and personal integrity. Between 2003 and 2005, the Ministry for Social Protection registered a total of 196 attacks against the Medical Mission, corresponding to a mean of one attack at every six days of the period 29 .

Another source of information, the National Association of Hospital Workers registered 633 attacks between January 2001 and September 2003, almost all of them attempts upon the life and the integrity of the health personnel: $49 \%$ threats, $29 \%$ displacements and $13 \%$ (corresponding to 84 cases) homicides, mainly of nursing personnel, physicians and health managers and promoters. This number of fatal victims corresponds to a mean of one homicide of a health worker at every twelve days during the 33 months covered by the report 30 .

As refers to violent acts against the infrastructure, especially ambulances are frequently frontally attacked or stolen for perfidious use for military purposes. A dramatic case was that of the ambulance of the municipality of San Carlos (Antioquia), which suffered three attacks in four years. During the last of these attacks, four of the occupants were killed: a nurse's aid, a women about to give birth and her sister.

Another serious problem is the blocking of shipments of medicine provisions to some communities by the armed groups, under the allegation that the medicines are destined to aid the combatants of the opponent group. The testimony of a native is very clear: The children die because there is no medicine for them. The old people die because they don't let ill people go to the town. The government tries to send medicine 
but the war does not allow it to arrive 31 . Thus, the distribution of medicine provisions for the treatment of leishmaniasis represents a military operation controlled by the Armed Forces. Whoever is in possession of the medicines is at risk of being categorized as insurgent or at least suspect of being one.

One must also not forget the situation of the about 40 health professionals, who during the last three and a half years became victims of arbitrary detention and responded lawsuits, accused of collaboration with illegal armed actors. Medical ethics and the International $\mathrm{Hu}-$ manitarian Law establish as one of the professional obligations of health professionals the provision of medical care to everyone without distinction. The circumstances of the conflict and the position of the present government denying the conflict are bringing the professionals into a complicated situation: if they provide care to the illegal armed actors, they can be sued by the government under the accusation of collaborating with the terrorists; if they don't, they are at risk of turning into a target of the nongovernmental armed actors ${ }^{32}$.

The attacks against the Medical Mission also contributed to epidemics and the reemergence of transmissible diseases. This was the case with the outbreak of yellow fever during the first months of 2004 in Sierra Nevada de Santa Marta and Catatumbo, where illegal armed groups had prevented the health units from developing preventive actions and providing treatment to the population. The same kind of actions in different areas of conflict led to reemergence of vector-transmitted diseases like malaria, leishmaniasis and Chagas' disease ${ }^{33}$.

In spite of the frequency and seriousness of the attacks against the MM and their impact on the health personnel and the services delivered to the population, the affected personnel receives only very little support from the State, governmental organisms and some humanitarian organizations. An active search carried out in 11 municipalities of the divisions Nariño and Boyacá 34 confirms this fact. Of the interviewed persons, $98 \%$ declared not having received any kind of support and only $2 \%$ declared having received some kind of working support. The same investigation emphasizes that $52 \%$ of the personnel had no knowledge at all about the International Humanitarian Law, 44\% had little knowledge and only $4 \%$, corresponding to the directors of hospitals, had adequate knowledge about the International Humanitarian Law.

\section{The limitations posed to health care by the armed conflict}

The internal armed conflict interferes in a number of ways in the access of the population to health services and hampers or hinders the health personnel to perform their medical activities, including health promotion, disease prevention, treatment and cure of the ill in conflict areas.

From the perspective of the health personnel, the armed conflict reduces the possibility, and in some cases comes impede the delivery, of the necessary and adequate health services. Some of the many mechanisms used for this were already described in the part about attacks against the Medical Mission. Under such circumstances, the working conditions in the health care institutions turn risky, unpleasant and stressing, and there are regions in the country where the delivery of medical services turns impossible due to the intensity of the conflict.

Another factor contributing to the worsening of the quality and integrity of the health services in conflict areas has to do with the availability and use of the resources of the sector. Bluntly put: all armed actors are interested in controlling the personnel, the installations and resources of the health sector in the conflict areas. To achieve this goal they resort to a range of mechanisms, from requests and warnings to threats, robberies, blockades, detentions and selective homicides. In Colombia, the interruption of energy turned into a strategy used by the insurgents for pressuring, intimidating and controlling the population. For the health sector, as for any other sector as well, energy is essential for the functioning of its infrastructure, illumination, diagnostic and surgical equipment and air conditioning. Reduction, loss or increased costs of resources result in less protection for the population, in an increased risk of certain diseases and lack of emergency assistance in violent events or other emergencies. This lack of protection ends up affecting the actors of the armed conflict themselves, eventually also becoming victims and needing medical care. This is the reason for the importance of defending the immunity of the health sector and the health personnel in fulfillment of their duty and of guaranteeing the recognition and compliance of all involved actors.

Reliable and timely information in the field of health is pivotal for formulating policies and establishing preventive actions, diagnoses and 
prognoses and for providing adequate assistance. If in general terms we are still facing serious difficulties with regard to the quality and reliability of information, in the areas of armed conflict information becomes a weapon difficult to find and, when existing, of difficult access. One can say that the first thing getting lost in war situations is complete and reliable information, and without information any kind of action, health actions included, turn more risky and uncertain.

\section{Conclusions and suggestions}

On principle every nation is sovereign and its citizens have the right to insurgence for putting an end to oppression and for constructing a more just society and State. But humanity succeeded in establishing some basic rules to be applied to wars between countries and inside countries, guidelines for avoiding and preventing excesses and norms for the protection of victims and the civil population. This is the purpose of the International Humanitarian Law. Without wanting to discuss here the legitimacy of the Colombian armed conflict, the documents and argumentations here presented allow concluding that in its present stage the mentioned conflict has violated the norms of the International Humanitarian Law, and that its dynamics are day-by-day violating the minimum requisites of humanity. The first step for overcoming this conflict lies in convincing the different parties and to grant that all armed actors really accept the international humanitarian laws. As long as for the actors everything is worth for achieving their particular objectives, there is no solution for the problem and the population, especially its most exposed and vulnerable members, will continue being the main victims.

The information presented in this article also provides elements for affirming that violence is the main public health problem Colombia is facing today. The high mortality rates from homicide; the significant deterioration of the quality of life not only of the direct victims of the armed conflict, but also of direct and indirect victims of other forms of violence; the physical and psycho-emotional morbidity as a consequence of the internal armed conflict; the always greater limitations to the delivery and access to adequate and efficient health care; the extremely high human, economical, demograph- ic and social cost of the violence, and the challenges it represents for the qualification of health personal, health research, policies and actions; and finally the delivered or not delivered services seem sufficient for emphasizing the role violence is playing in the national public health problem. This is not about not recognizing or underestimating other serious pending public health problems; this is about facing reality and defending the elementary right to life.

More as a conclusion than as a hypothesis, one can affirm that the life, the health and the well-being of the Colombian people are clearly the losers in the conflict the country is living. The more than half million lives, which were sacrificed during thirty of the forty years of the armed conflict, are the main reason for this but not the only one. Although in the original ideology of some of the historical actors of the conflict the right of the population to health and a decent life might have occupied some place, things took another course somewhere on the way and today this right is denied to people by the imperatives of an overflowing war. For the health professionals and the public in general it seems ethically incorrect to bet on a war in which their cause - life and well-being for all is already defeated and does not seem to interest any of its protagonists, unless for the purpose of a tranquilizing discourse.

The core of the Colombian problems - the armed conflict included - is rooted in an ancient and ever increasing inequality in all sectors of social life. As refers to health and quality of life, these inequalities came to reach scandalous levels as shown by the inequality before death, the unequal distribution of resources and access to the health services. The efforts towards equity in health as part of a global project of equal rights for all are the basic sense of the statement right to health is a bridge to peace. If one of the original motivations for the today overflowing confrontation were revolt against inequality and the fight for equity, efforts towards equal rights to health would be the right direction for a radical solution of the problem. On the other hand, passively accepting or actively sustaining a health care model that deepens inequality would mean nourishing the conflict and jeopardizing any possibility of solution.

What is it public health can do about violence? First of all, public health has to recognize violence as one of its concerns. This is not a question of taking possession of violence or of 
trying a medical approach to it; this is about recognizing violence as part of public health concerns and interests. Public health, together with other fields of knowledge, should contribute to the comprehension and to the solution of the phenomenon. The nature of violence transcends the field of public health but its negative impacts on the life and the well-being of individuals and the society are of concern for public health. It must be emphasized that the worst thing public health could do with respect to violence - and this is equally true for armed conflicts - would be continue ignoring it or continue considering it as something beyond control, distant and almost impossible to face.

In fact, public health can contribute greatly to the study of violence, to its registry and investigation, to proper care to its victims, to a joint formulation of strategies, policies and programs for preventing or facing it, to the qualification of personnel prepared for facing violence, and for encouraging positive values. No matter the difficulties and risks involved, public health can and has to make front to situations of armed conflicts like the one Colombia is living.

\section{Collaborations}

S Franco, CM Suarez, CB Naranjo, LC Báez and P Rozo have participated to an equal extent in the preparation of the present article.

\section{References}

1. Comité Internacional de la Cruz Roja. Comentario del Protocolo del 8 de junio de 1977 adicional a los Convenios de Ginebra del 12 de agosto de 1949 relativo a la protección de las víctimas de los conflictos armados sin carácter internacional (Protocolo II). In: Oficina en Colombia del Alto Comisionado de las Naciones Unidas para los Derechos Humanos. Compilación de jurisprudencia y doctrina nacional e internacional. Bogotá: Plaza y Janés Editores; 2003. v. 3, p. 41.

2. Guzmán G, Fals O, Umaña E. La violencia en Colombia. 2a edición. Bogotá: Editorial Taurus; 2005. p. 1323.

3. Fundación Seguridad y Democracia. Avaible from: www.seguridadydemocracia.org

4. Vargas R. Fumigación y Conflicto. Políticas antidrogas y deslegitimación del Estado en Colombia. Bogotá: Tercer Mundo Editores; 1999.

5. Franco S. El Quinto: no matar. Contextos explicativos de la violencia en Colombia. Bogotá: Iepri, Tercer Mundo Editores; 1999.

6. Programa de las Naciones Unidas para el Desarollo. Boletín Hechos del Callejón 2005; 2:2-4. 
7. Programa de las Naciones Unidas para el Desarollo. El conflicto, un callejón con salida: Informe de Desarrollo Humano 2003. Bogotá: PNUD; 2003. p. 121.

8. Organización Panamericana de la Salud. Situación de salud en Colombia. Indicadores básicos 2004. Bogotá: OPS; 2005.

9. Rojas J. Notas sobre desplazamiento. Bogotá; 2006. Impresso.

10. Ospina P, Vega A, Garzón LM, Morris C, Guy S. Capacitación y servicios de salud sexual y reproductiva para jóvenes desplazadas en Colombia. Revista Migraciones Forzadas 2003; 15:7-14.

11. Rico A, Castillo O. Población en situación de desplazamiento en Colombia. Bogotá: Secretariado General de la Pastoral Social/Sección Movilidad $\mathrm{Hu}$ mana; 2004.

12. Organización Panamericana de la Salud, Universidad de Antioquia. Series de Salud y Desplazamiento. Modulo No. 1. Medellín: OPS; 2003

13. Consultoria para los Derechos Humanos y el Desplazamiento. Niños desplazados por la violencia: rostros inocentes de una tragedia acumulada. In: Un país que huye: desplazamiento y violencia. 2a edición. Bogotá: Publicaciones Codhes; 2003.

14. Red de la Solidaridad Social [cited 2005 Dec 20]. Available from: www.red.gov.co/estadisticasparamedios/.

15. Consultoria para los Derechos Humanos y el Desplazamiento. Boletín Codhes Informa 2004; 48.

16. Programa de las Naciones Unidas para el Desarrollo. Informe de Desarrollo Humano 2003; p. 121-123.

17. Consultoria para los Derechos Humanos y el Desplazamiento. El desplazamiento forzado interno en Colombia. Bogotá: Codhes; 2002.

18. Consultoria para los Derechos Humanos y el Desplazamiento. Informe especial: los indígenas en Colombia: entre el hambre y el miedo. Bogotá: Codhes; 2004.

19. Centro de Investigación y Educación Popular, Justicia y Paz. Noche y Niebla: Banco de Datos de Violencia Política 2002; 26.

20. Comité Internacional de la Cruz Roja. Informe de actividades 2004. Bogotá: CICR; 2004.
21. Programa de las Naciones Unidas para el Desarollo. Boletín Hechos del Callejón 2005; 3:9-11.

22. Las minas cercan a 289 pueblos más. El Tiempo 2006 marzo 24; p. 1.

23. Campaña colombiana contra Minas. Monitor de minas terrestres 2004. Bogotá; 2004.

24. Programa de las Naciones Unidas para el Desarrollo. Boletín Hechos del callejón 2005; 4:12-14.

25. Organización de las Naciones Unidas. Informe de Secretario General. Documento E/CN.6/2000/PC/2.

26. Republica de Colombia. Ministerio de Protección Social. Manual de uso del emblema protector de la Misión Médica en Colombia. Bogotá: Ministerio de Protección Social; 2003

27. Comité Internacional de la Cruz Roja. Infracciones a la Misión Médica en el Conflicto Armado Colombiano 1995-1998. Bogotá: CICR; 1999.

28. Ministerio de la Protección Social, Organización Panamericana de la Salud/Organización Mundial de la Salud. Manual de la Misión Médica. Bogotá: Ministerio de la Protección Social, OPS/OMS; 2004.

29. Republica de Colombia. Ministerio de la Protección Social. Infracciones reportadas 2003-2005. Bogotá: Comunicación personal; 2006.

30. Plataforma Colombiana de Derechos Humanos.Una misión maltratada por la guerra. In: El embrujo continúa. Bogotá: Antropos; 2005. p. 239-243.

31. Médicos por la guerra. Los rituales mágicos de los Jaibanàs [cited 2003 Dec]. Available from: www. eltiempo.com.

32. ¿Presos por atender guerrilleros? Médicos, en el dilema de la guerra. [cited 2004 Nov]. Available from: www.eltiempo.com.

33. Ataques de grupos armados contra misiones médicas pasaron de 29 en 1999 a 239 en el 2002. [cited 2004 Sep]. Available from: www.eltiempo.com.

34. Báez L, Madroñero V, Franco S. El conflicto armado interno y su impacto sobre la Misión Médica en Colombia. El caso de once municipios en Nariño y Boyacá. Revista Odontología 2003; 22(2):23-29.

Article presented in 4/03/2006

Approved in 17/03/2006

Final version presented in 17/03/2006 